\title{
Blue Economy is the Economic Activities that Directly or Indirectly Take Place in the Ocean and Seas, Use Outputs, Goods and Services into Ocean and Land Based Activities
}

\author{
AS Ninawe* \\ Department of Biotechnology, Maharashtra Animal and Fishery Sciences University, India \\ *Corresponding author: AS Ninawe, Department of Biotechnology, Maharashtra Animal and Fishery Sciences University, India

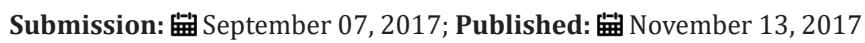

\section{Commentary}

United Nations agenda on Sustainable Development (Projected SDG Goal-14 by 2030) is on conservation, sustainability and use of oceans, seas and marine resources for increasing the economic benefits to Small Island developing states and least developed countries for sustainable use of marine resources, including sustainable management of fisheries, aquaculture and tourism. Blue economy has great potential for boosting the economic growth, employment and sustenance of economy (Figure 1). It supports food security, managing and protecting the ocean environment, creation of high value job and diversification to address new resources for energy, new drugs and value chemicals, protein food, deep sea minerals, security and threats including services to human welfare and measures for resilience climatic changes. Considering its wide range of valuable resources, the Blue Economy is gaining increasing interest in Indian Ocean Rim Region for the economic development and for the human welfare. Indian Ocean supports with wide array of biodiversity and ecosystem resources from mangroves, coral reefs and sea-grass beds to deep oceans and provides economic value products and services such as high nutritious food and livelihood.

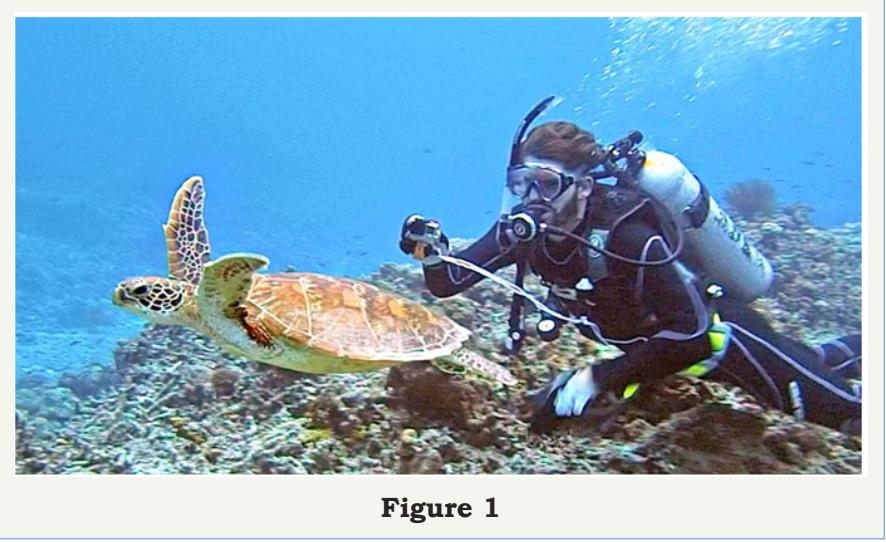

India has a coastline of above 7,500 km, spanning into nine maritime States and two Union Territories (UTs) in the mainland, and two island UTs with 12 major and 187 non-major ports, which plays crucial role in sustaining growth for trade and commerce. The largest coastline supports various enterprising activities in inland waterways and port based activities. Blue economy supports $95 \%$ business with sea transportation, oil and petroleum resources using Indian Ocean as the economic hub. Although Indian Ocean is endowed with rich wealth of natural resources it is yet to be fully tapped for economic development from ocean, seas and coastal resources for harnessing high value products and processes. India's Exclusive Economic Zone (EEZ) extends to 2.02 million sq $\mathrm{km}$ and the continental shelf area to 0.18 million sq $\mathrm{km}$. The Indian coast support about $30 \%$ of 1.25 billion Indian populations and the ecosystem is known for high biological productivity for rich fauna and flora. The exploited marine fisheries resources from the coastal area have been reported maximum from the present fishing grounds up to $200 \mathrm{~m}$ depth. However due to urbanization and anthropogenic activities, the coastal fisheries are being faced with several threats due to indiscriminate fishing, habitat degradation and pollution.

The economic activity in the ocean is based on the rapidly expanding ocean industries combined with large industries like maritime and coastal tourism, offshore oil and gas, shipbuilding and maritime equipment. There lies great potential for marine aquaculture, capture fisheries, fish processing, offshore wind, and port based activities to provide employment especially in marine aquaculture, fish processing, offshore wind etc. Globally, the market of certified sustainable seafood is growing at a rate of $35 \%$ per annum and has been increasing constantly through exports of frozen shrimp and other products. Among the coastal states Gujarat, Andhra Pradesh, Kerala are contributing high in quantity and value of exports and produce is marketed in United States, South East Asia and European Union. The demand is continuously growing for marine resources of food, energy, minerals and novel products.

The blue economy measure supports fisheries, sea energy, ports and naval sea bed, ocean studies and marine biotechnology research. It also supports various other sectors viz. fishing capture, 
fishery and aquaculture, novel marine products of high value drugs, chemicals and bio-products, mineral resources for oil and gas, deepsea mining and hydrocarbon, renewable energy resources for wave energy projects and offshore wind energy. In manufacturing sector it provides support for boats, fishing nets, under-water equipment/ devices and mariculture structures like rafts, cages, pens etc. The construction at the coast and sea and to the mainland is also a high promising sector of blue economy for employment generation.

It is a powerful engine for shipping and ports for fishing harbors and shipyards. The sea treasure has been a great excitement for the scientific community and the public. It provides opportunities for tourism for coral dives and fishing for which boating and surfing, swimming and diving. Various other economic sectors like financial service to coastal community, meteorological consultancy and geoinformatics, submarine telecom provides high end opportunities. The inventorisation and digitalization of resource mapping through satellites and imaging system supports identification of fishing grounds and climate warning systems with ICT linkages can produce relevant database for operational management. In 21st Century Global initiatives are being taken on blue economy by various countries like Australia, European Union, China and also by India and many more countries are in the race in harvesting the ocean resources giving emphasis on blue economy especially on coastal security, economic and environment activities in the maritime domain and sustainable development of sea based resources. India in collaboration with neighbouring nations is promoting the blue economy based activities in Indian Ocean with emphasis on environmental sustainability issues.

The current focus is confined to marine products, including minerals and metals with focus on non-living resources. The sector can support the developmental activities in maritime region to provide shipping services and infrastructure creation that supplements infrastructure on land, mechanised floating port, geoengineering, environment-friendly and also the developments in hinterland through inland waterways, obviating the need for trucks or railways. A focus on R\&D through innovation and discovery driven projects from coastal, estuarine and sea are creating opportunities to explore new marine living resources, energy and alternate fuel, minerals and metals bio-materials, tapping new proteinaceous food and nutraceuticals. India's research capabilities in modern marine biology and biotechnology can capitalise from vast marine biodiversity in a sustainable manner. A focus on basic and applied research in marine biology, marine ecology and marine biotechnology with multidisciplinary science can produce novel bio-molecules and processes for therapeutics, enzymes, hormones, bio-plastics, metabolites etc.

It has been a powerful engine for potential economic growth and employment generation in addition to sustainable livelihood for the coastal community. It provides unique opportunity to explore marine biodiversity to study the ecosystems of coastal, mangrove, sea grass, seaweed, estuarine, lagoon, pelagic, benthic
The rapid expansion in maritime and coastal activities including tourism, offshore oil and gas, shipbuilding and maritime equipment are likely to emerge a major source of employment generation through blue-economy. The promising blue economy technologies that could offer sustainable employment generation from fisheries and aquaculture, marine transportation, offshore oil \& gas, ocean renewable energy, marine recreation, defence \& security, coastal \& ocean management, Tsunami early warning system. It can engage large workforce, especially in marine aquaculture, fish processing, offshore wind and port activities and could include inclusive development, poverty alleviation.

The ocean is being used as hub confine to focus on marine products, including minerals and metals for supporting activities, such as shipping services and infrastructure creation that supplements infrastructure on land, mechanised floating port, geo-engineering. The environment-friendly activities in hinterland through inland waterways can support creation of skilled and unskilled employment. It can accelerate the technological empowerment of the coastal people to get them engaged in various developmental projects. The potential employment sector is aquaculture and fisheries for culture, harvest, processing, aquaculture engineering and value addition etc. Indian Ocean being highly productive and rich with eco-system, creating large career opportunities for skill development, entrepreneurial development and creation of vocational manpower for promotion of ocean economy based developmental activities.

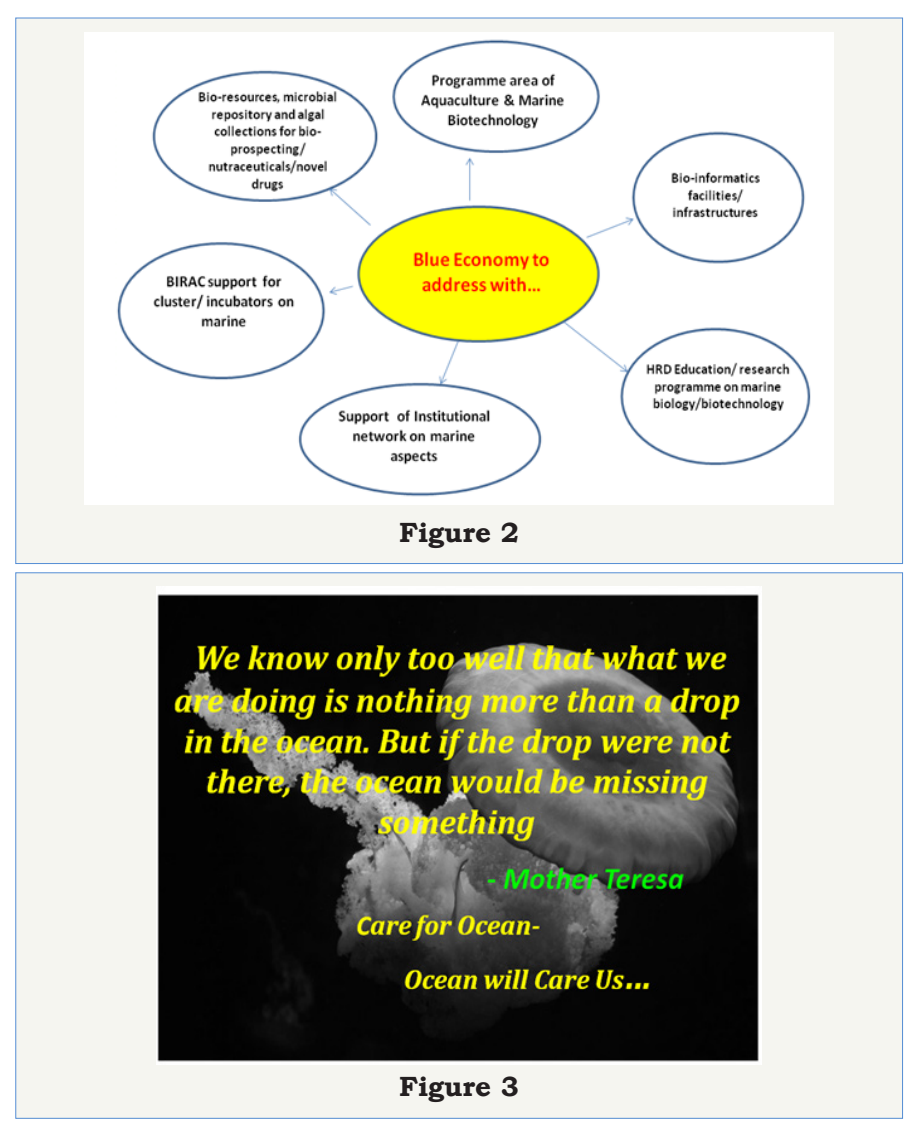




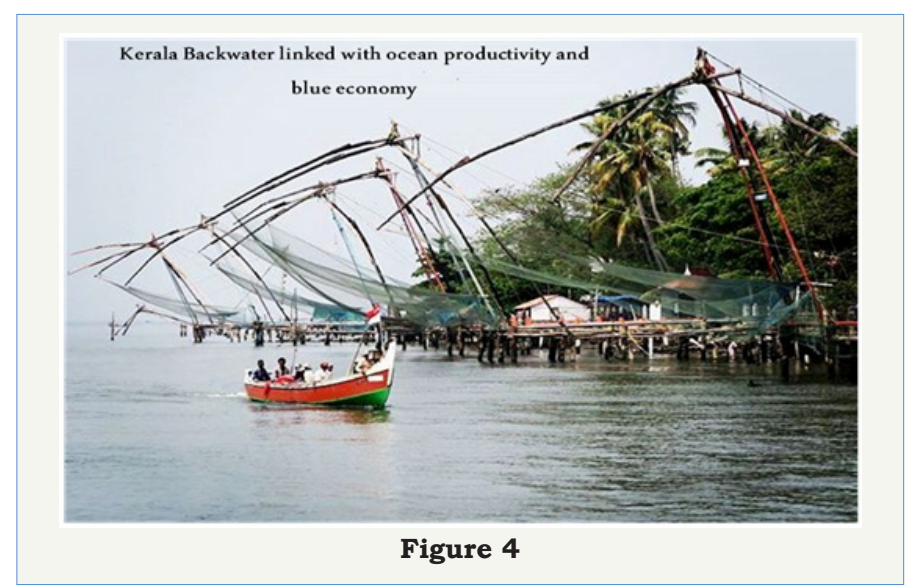

Scientists and technologists in Government Institutions, Research Institutions, Foundation and Trusts can get good career opportunities through blue economy measure in research and developments. High calibre scientists and professionals are engaged with their specialization by the Government Departments' viz. Ministry of Earth Sciences, CSIR, DST and DBT as lab scientists in their constituent autonomous bodies and institutes as policy managers. Huge opportunities exists in engaging trained human resources in the establishment of international exchange programme in fostering international S\&T collaborations in ocean science and technology and stimulate innovation in diversified marine and maritime activities. The opportunities exist for entrepreneurs for development of ocean-based industries for promotion of bio-business. Maritime sector also attracts to young people in coasts and seas and engaged them in harnessing the potential of seas and coasts for sustainable growth. Students with Master's education in marine biology, marine engineering and ocean sciences are in high demand in exploration of sea wealth and resources off shore oil exploration etc. apart from their involvement in port based activities and in oceanarium sector as curator etc. They are engaged in various technical jobs in cruise operations and management (Figure 2-4).

\section{Acknowledgement}

The author is presently working in the Department of Biotechnology as Scientist "G" and Advisor, dealing with the Programme area of Aquaculture and Marine Biotechnology. The views expressed are of Authors and not that of the organization to which he belongs. 